\title{
First evidence of accumulation of mega boulders on the Mediterranean rocky coast of Provence (southern France)
}

\author{
C. Vella, F. Demory, V. Canut, P. Dussouillez, and T. J. Fleury \\ CEREGE, UMR 6635, CNRS Aix-Marseille Université, BP 80, 13545 Aix en Provence, cedex 04, France
}

Received: 10 November 2010 - Revised: 25 January 2011 - Accepted: 26 January 2011 - Published: 23 March 2011

\begin{abstract}
An accumulation of boulders was recently discovered along the rocky coast of the Gulf of Fos located in Provence, in an area exposed to a south-westerly wave regime. The coast around this locality forms the western extremity of the calcareous Nerthe range between Marseille and the Rhône Delta. Several mega blocks are scattered to a distance of $30 \mathrm{~m}$ behind the coast line. The largest block (33.5 tonnes) has been transported about $39 \mathrm{~m}$ inland, up to about $2 \mathrm{~m}$ a.s.l. On the Mediterranean coast, the origin of such blocks is often attributed to tsunami-generated waves, but in the case examined here, although the origin is unclear, the differences in surface state between boulders indicates several events generated by south-westerly storms. Radiocarbon dating on several different shells collected from seven different boulders yields a wide dispersion of ages ranging from $4000 \mathrm{BP}$ to the Modern Period. The differences in surface appearance, as well as the differences of fauna conservation and surface coloration, in some cases in a very fresh state, along with the dispersion of radiocarbon ages, suggest that historic storm events have affected these megablocks.
\end{abstract}

\section{Introduction}

After the Indian Ocean tsunami of 26 December 2004, the attention of the scientific community concerning this seismic marker highlighted the possibility of estimating the return times of such events and placing constraints on the maximum inland penetration of flooding. The effects of the recent storm Xinthya on the Atlantic coast of France have shown up the limitations of the risk maps in France. Boulder ac-

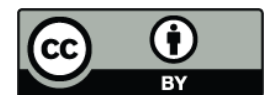

Correspondence to: C. Vella (vella@cerege.fr) cumulations are also a signature of storms and could help in the coastal management of urbanized zones. In addition, the role of catastrophic events in the morphological evolution of the rocky coast of Provence has been neglected. While recent studies of cliffs at Cassis (Recorbet et al., 2010) indicate catastrophic slides and rockfalls, the coast of Provence has also been the site of unusual tsunami events, even though the waves generated by earthquakes are moderate (Pelinovski et al., 2001, 2002).

Boulder accumulations are observed along rocky coast all over the word. They are mainly interpreted as the signature of tsunami events, but in some case boulder accumulations are markers of tropical cyclones or storm events. While there is no ambiguity for observations of recent tsunamis (Goff et al., 2006; Goto et al., 2007), large boulder accumulations may be associated with historic and prehistoric events related to tsunamis (Nott, 2000; Mastronuzzi and Sansò, 2000; Williams and Hall, 2004; Mastronuzzi et al., 2007; Maouche et al., 2009; Paris et al., 2009). Nevertheless, we cannot rule out the possibility of transport by storms (Barabano et al., 2010), and some recent case studies show the role of storm waves in forming boulder accumulations worldwide (Noormets et al., 2002; Nott, 2004; Goto et al., 2009, 2011; Suanez et al., 2009; Etienne and Paris, 2010).

The coasts of Greece, southern Italy, Algeria, and the Eastern Mediterranean basin are known for the occurrence of boulder accumulations interpreted as tsunami deposits (Kelletat and Schellmann, 2002; Mastronuzzi and Sansò, 2000; Morhange et al., 2006; Vött et al., 2006; Scheffer and Scheffers, 2007; Maouche et al., 2009), but to a lesser extent compared with storm events (Mastronuzzi and Sansò, 2004; Barbano et al., 2010). The effect of storms on the accumulation of boulders in Provence is unknown. Therefore, the question of the origin of these boulder accumulations is important for understanding the geomorphological processes and assessing

Published by Copernicus Publications on behalf of the European Geosciences Union. 


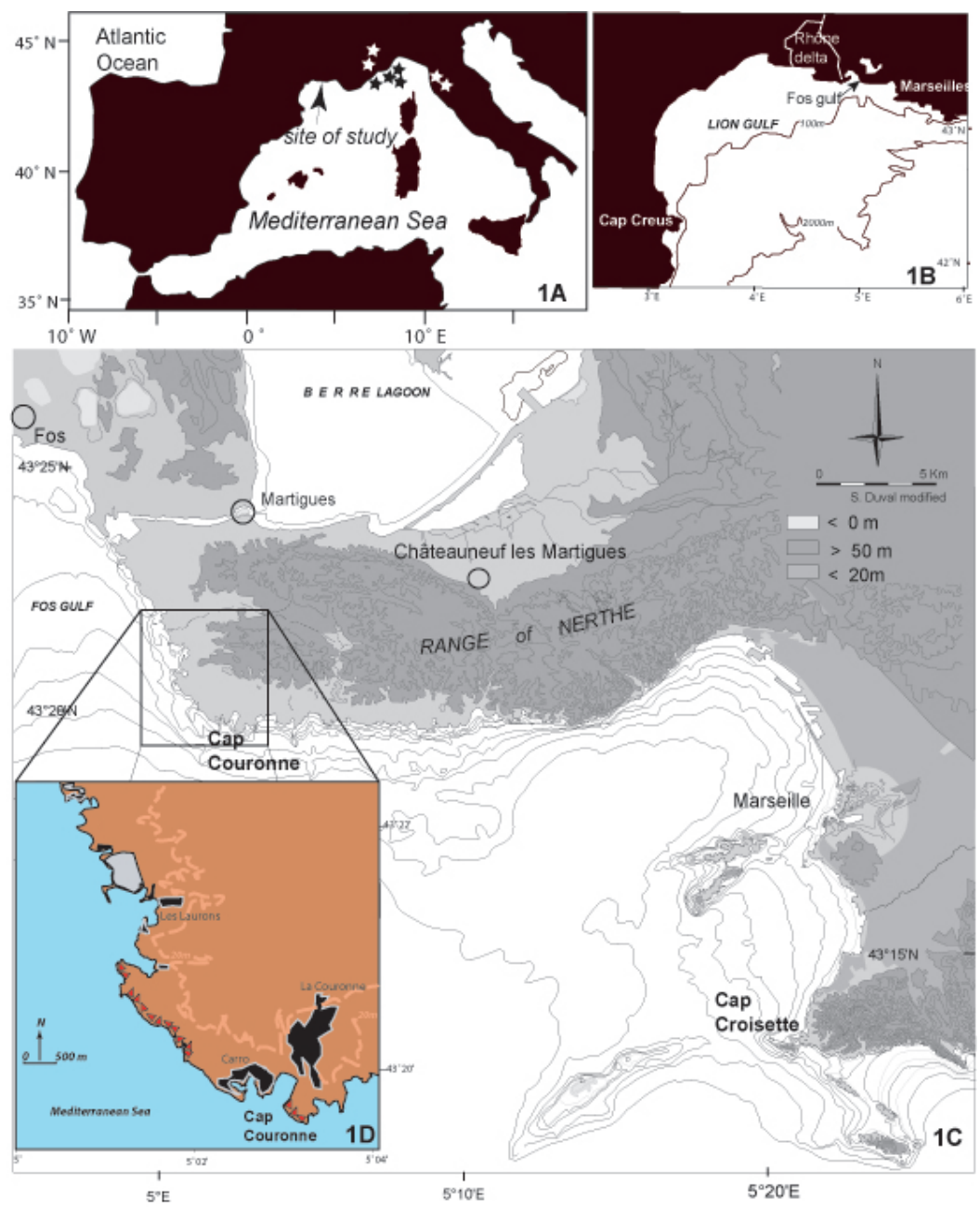

Fig. 1. Location map of the study area. (A) The arrow indicates the zone of study and stars indicate epicentres of earthquakes induced tsunamis on the french coast of metditerranean (from Pelinovski et al., 2001, modified). (B) The studied zone is very exposed to the waves and the swells from the West and the southwest. (B and $\mathbf{C}$ ) The studied coast is protected by the cape Couronne and the cape Croisette of the swells from east and southest. (D) The red triangles localize the zones of blocks.

the local risk to the population and economic activities. The boulder accumulations are situated very close to the largest industrial port of France, in the Gulf of Fos (Fig. 1). In this paper, we report evidence of cataclysmic waves events affecting the rocky coast of Provence and present the first dating results on these boulder accumulations.

\section{Methods}

All topographic data and the locations of the blocks have been collected using a differential GPS RTK Trimble. The vertical accuracy of the measurements ranges between 0.6 and $1 \mathrm{~cm}$ after post-processing in laboratory. For the areal topography, the same method has been used to make a WSW topographic profile, along the most probable direction of the wave propagation. The bathymetric profiles have been obtained from SHOM database from 1976 after digitalization and GIS geolocalization.
All dates were calibrated using Calib rev 5.0.1 (Reimer et al., 2004; Stuiver et al., 2005). Marine reservoir effect is estimated from local comparison with ${ }^{14} \mathrm{C}$ results obtained from local stratigraphic data on the Holocene ria infilling (Vella et al., 2011). We obtained a calculated local reservoir age of $570 \pm 78 \mathrm{yr}$. These results are consistent with eight ${ }^{14} \mathrm{C}$ ages obtained on "pre-bomb" mollusc shells collected in the Gulf of Lions between 1873 and 1907 (Siani et al., 2000) and recent archaeological data from the Thau lagoon near Sète (Court-Picon et al., 2010).

\section{Geological and geomorphological setting}

The studied area is located on the Mediterranean coast of France, situated on the eastern flank of the Gulf of Lion, on the western part of a small calcareous massif (called the Nerthe range) between Marseilles and the Rhône delta (Fig. 1). The Nerthe range is located at the westernmost 


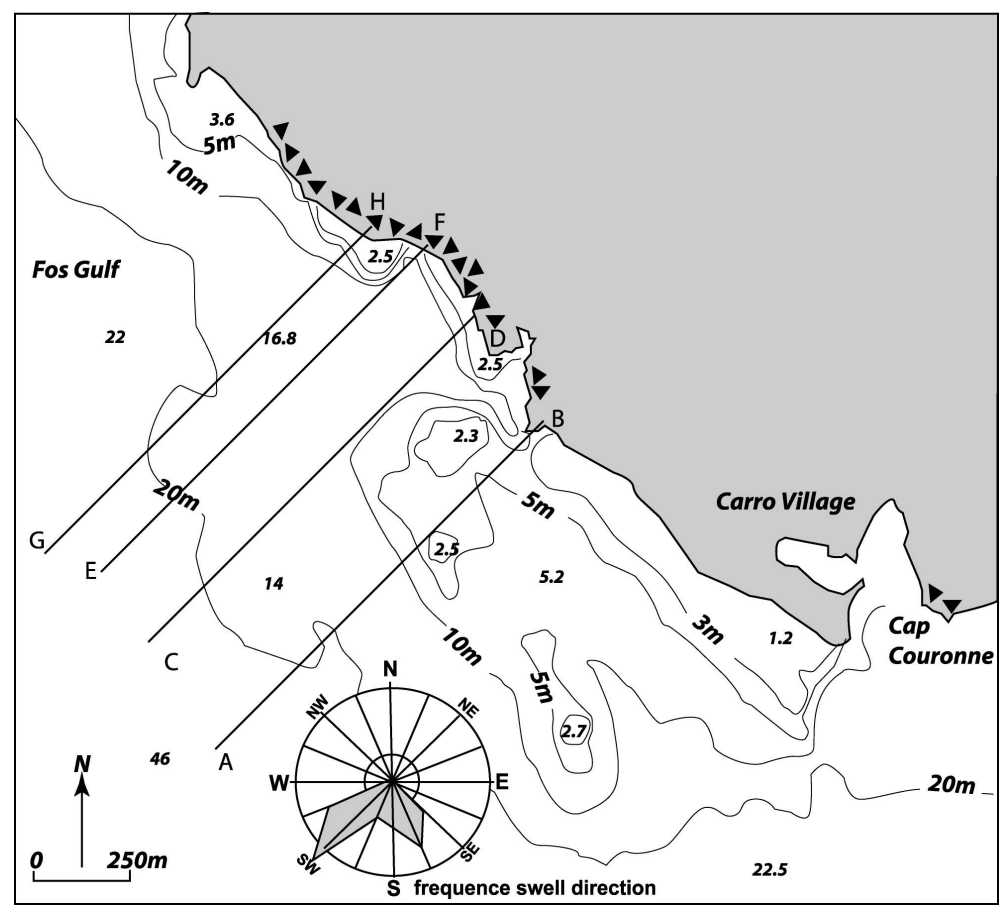

Fig. 2. Bathymetric map with positions of boulders (dark triangles) and location of profiles. Frequency of swell from Cap Couronne between 1964-1978.

extremity of the rocky coast of Provence, and represents a major geological boundary between the calcareous massifs of Provence to the east and the Rhône valley to the west. The morphology of the rocky coast depends on lithostructural conditions. Miocene calcareous rocks dip gently towards the Gulf of Lion and the south-west. In the Gulf of Lion, a Pleistocene/Holocene succession overlies the calcareous substratum under the Gulf of Fos and extends towards the Rhône delta. Under the sea, the gently dipping Burdigalian limestones sometimes form a structural platform, of epigenetic and bioerosive nature, which emerges above sea level to form a weakly sloping extension of the same platform. The orientation of the eastern coast of the Gulf of Fos $\left(160^{\circ} \mathrm{N}\right)$ is also attributed to a group of tectonic faults $\left(160^{\circ} \mathrm{N}\right)($ Chorowitz and Paul, 1974). The tectonic activity of this area is not clearly established, but the sedimentary evolution of the sandy coast in the north of the Gulf of Fos seems to indicate that rapid changes of coast line position could be linked to tectonic events. In addition, a comparison of two regional relative sea-level curves for the end of the Holocene reveals an unexplained shift after $2000 \mathrm{BP}$ (Vella and Provansal, 2000; Morhange et al., 2001; Vella et al., 2005). However, there is no evidence for tectonic activity during the Holocene, and the magnitude of the shift between the two curves is inconsistent with the regional rates of tectonic movement.
The submarine platform (Figs. 2 and 3) and pebble beach ridges present along the coast limit the action of the sea on the emerged continent. No boulder is visible on these parts of the coast. The bathymetric profile of the sea bed shows a shallow platform between 0 and $-10 \mathrm{~m}$ water depth (profile A-B), extending up to $600 \mathrm{~m}$ from the coast line.

In some cases, the limit between the sea and the land is formed by a metre-high cliff and the submarine profile shows an abrupt slope. A water depth of $10 \mathrm{~m}$ is rapidly attained at just a few metres from the coast line. Boulder accumulations are localized on specific sections of the coast, in areas where the submarine platform is systematically absent seaward of the zone of accumulation (Figs. 2 and 3).

The shoreline is subject to a microtidal regime $(30 \mathrm{~cm}$ average tidal range), and is essentially affected by wave action and wave-generated currents. Waves come from two prevailing directions. The most frequent swell directions are associated with NW-NNW onshore winds (Mistral) and SW winds. The coast in the study area is sheltered from waves associated with winds from the SSE and ESE.

The wave climate is well known. SW and WSW wave directions have always been associated to NW to NNW winds and lower energy events compared to SE events. Indeed, if the most frequent direction is SW (30\% of the total regime, cf. Fig. 2), these waves are rather low energy with heights of 0.5 to $1 \mathrm{~m}$ and modal period less than $6 \mathrm{~s}$. Although waves from SSE and ESE represent $16 \%$ and $11 \%$ of the total annual regime, respectively, there are high-energy waves more 


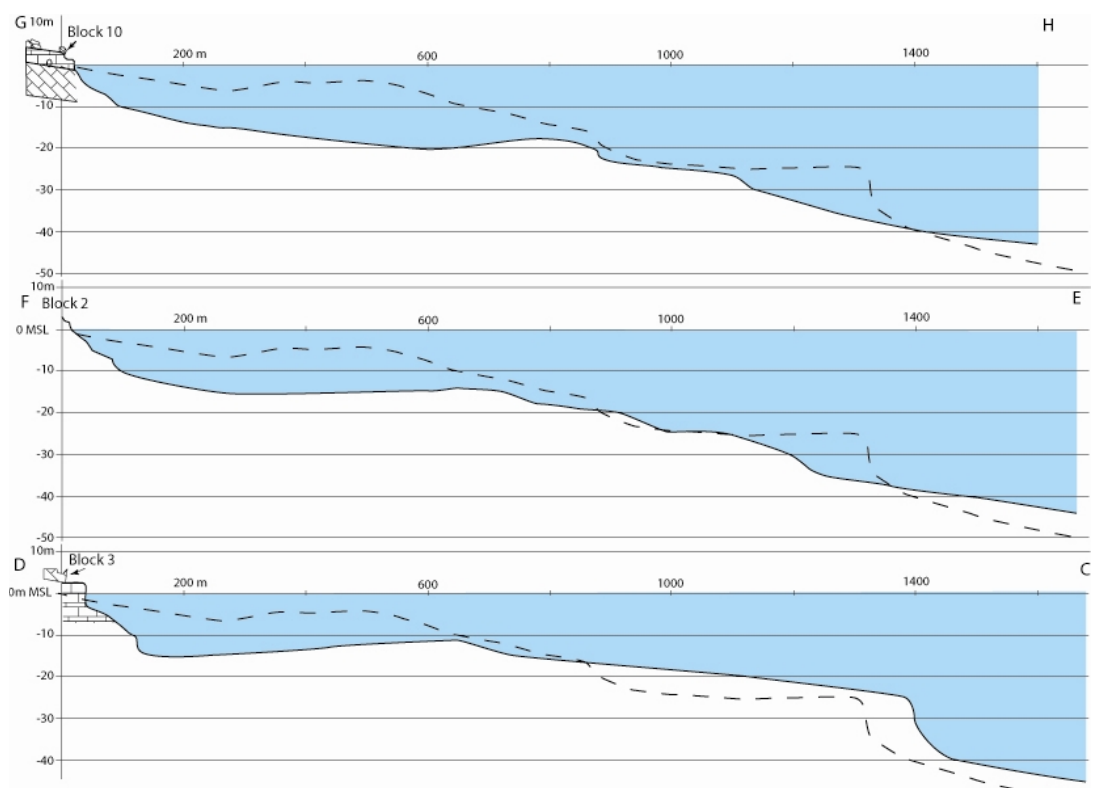

Fig. 3. Bathymetric profiles on seaward side of boulder accumulations, compared with profile A-B (cf. Fig. 2), indicated as dashed line, devoid of megaclast deposits.

than $2 \mathrm{~m}$ high in more than $40 \%$ of cases and with periods longer than $6 \mathrm{~s}$ in more than $25 \%$ of cases (Sabatier et al., 2009). However, a part of the SW waves can also be associated to rare winds of same direction producing higher energy waves. Ullmann et al. (2008) have shown that sea surge during storm event could happen with different direction of wind and is fonction of local orientation of the coast. The scarce wind databases of the Gulf of Lion do not allow to clearly evidence the strongest SW events.

\section{Boulder accumulations}

Boulder accumulations in some cases form isolated megablocks, which are located at three levels (Fig. 6a) (i) on the supratidal or subtidal zones, (ii) as imbricated megaclasts on the supratidal zone and (iii) at the top of the cliff or on the sub-aerial platform, making up an elongated boulder train parallel to the coastline (Fig. 6b). Although we did not carry out a statistical analysis of the orientation of the blocks, we simply note that the orientations are relatively varied, with trains of blocks following directions between $80^{\circ} \mathrm{N}$ and $16^{\circ} \mathrm{N}$ (Fig. 4). The long axis of the elongated blocks studied here, are oriented along a SSW to W direction. This orientation is parallel to the probable direction of the waves. Usually the elongated boulders tend to dispose their long axis tangent to the direction of waves, as suggested by many autors (Mastronussi and Sansò, 2000; Paris et al., 2009). In some cases of the present study the long axes are not oriented in this direction because the blocks have been hampered by microcliffs and slopes. The long axis of

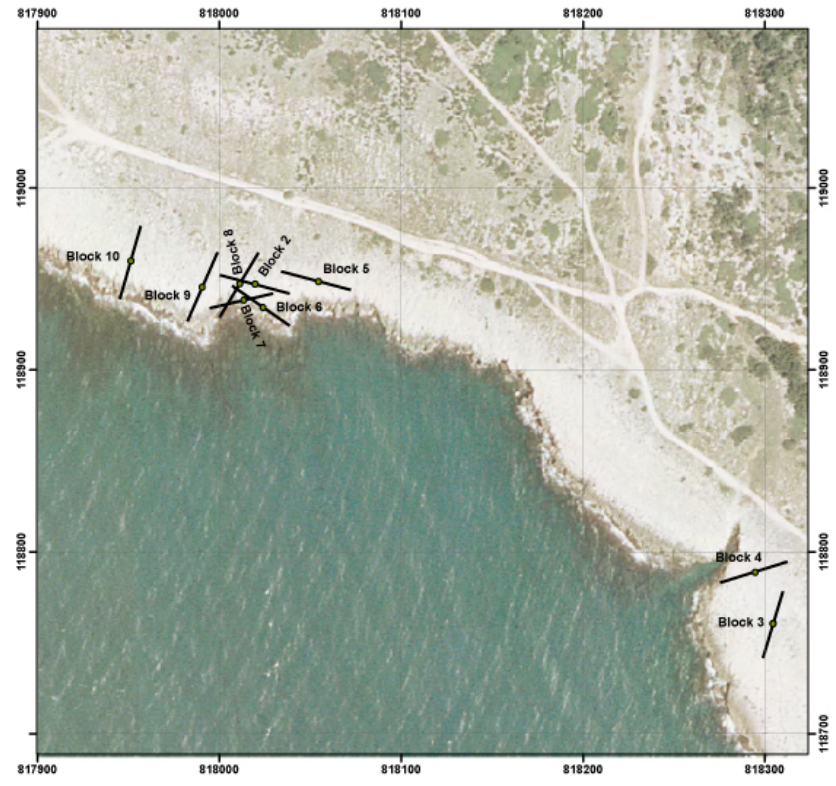

Fig. 4. Long axis orietation of elongated boulders studied (indicated as black full line).

blocks in such a case is oriented between $303^{\circ} \mathrm{N}$ and $322^{\circ} \mathrm{N}$ (Fig. 6c). The maximum distance of the clast accumulations from the sea is around $100 \mathrm{~m}$. We note a grading of clasts in the most part of the site. Indeed, the smallest blocks are systematically situated furthest from the shoreline. A large proportion of the clasts have slipped off from the top of the cliff or from the sub-aerial platform, but some blocks show 


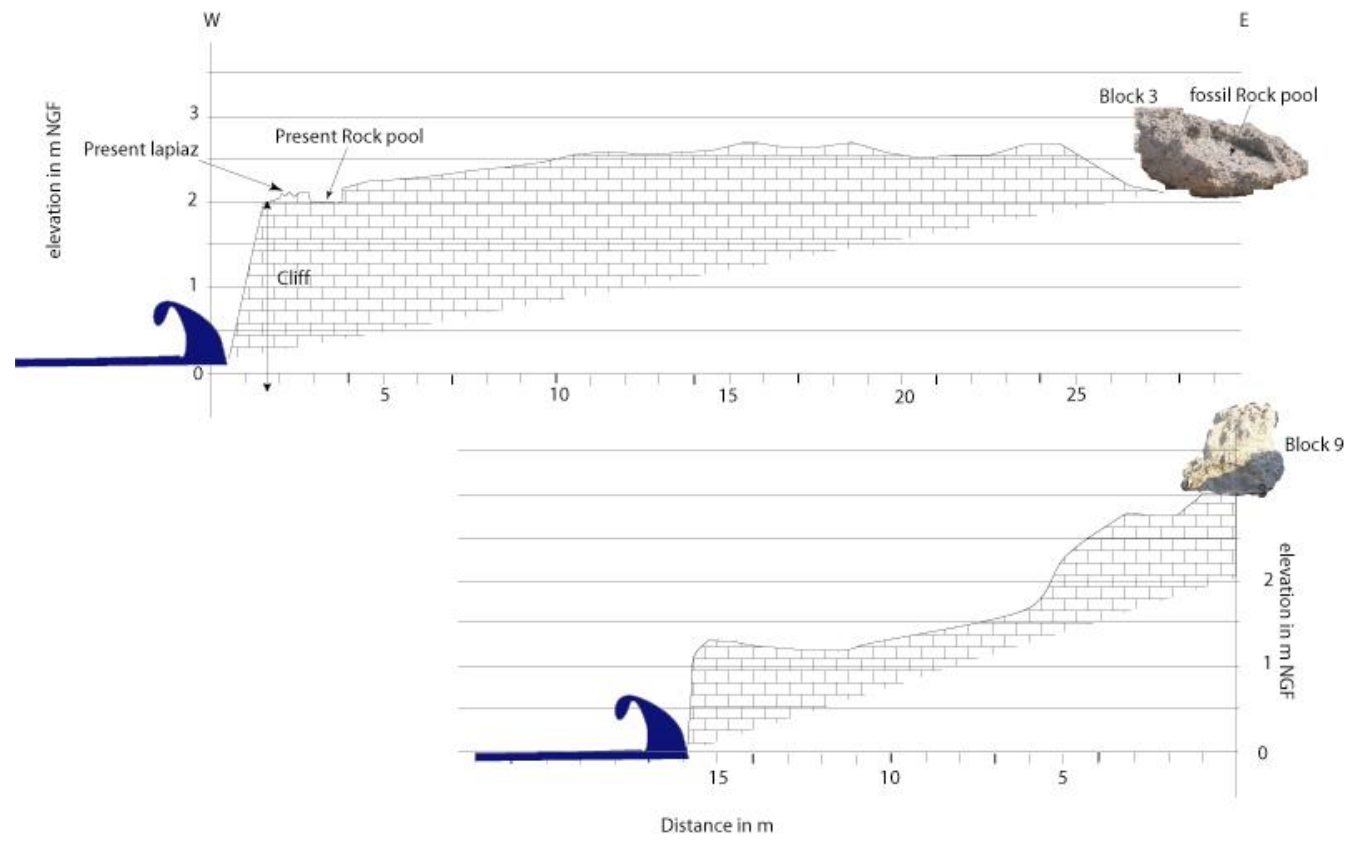

Fig. 5. Location on the aerial profiles of blocks with biological inscrustations, and mega-block 3 with karst morphology marks.

features typical of the middle shore zone. Some blocks are marked by middle-shore notches (Fig. 6d) or coastal karst morphology (lapies and rock pools). A particular type of fauna is associated with blocks exhibiting notches formed on the middle-shore. The base of abrasion of the notch is bored by lithophagous molluscs (Lithophaga lithophaga) and colonized by tube worms (Vermetidae). The blocks show some typical features of the middle or lower shore zones. Mechanical and biological traces characteristic of karstic erosion are recorded on the top of certain blocks. These blocks were subsequently moved away from the zone of swell and biological action at the base of the lower shore. Certain blocks show perfectly preserved rock pools and lapies, but they no longer occupy positions compatible with the original conditions of their formation. Rock pools are truncated (Fig. 6e), while the coastal lapies is knocked down or strongly tilted (Fig. 6f).

\subsection{Biological evidence of transport from the middle shore zone}

Numerous blocks show biological traces of prolonged residence in the sea (Fig. 6g, h, i and j); they are not only microperforated by boring sponges, but, more importantly, also contain perfectly round holes several $\mathrm{cm}$ deep caused by the action of rock-borers (Fig. $6 \mathrm{~g}$ ) such as lithophagous molluscs (Lithopha lithophaga). Certain blocks also show traces of marine encrusting animals such as Balanus sp. and Vermitidae. These animals are characteristic of the lower shore zone, below the middle shore, (Fig. $6 \mathrm{~h}$ and i), but some seaweed are exceptionally preserved, such as the rim of Lithophyllum bissoïdes in block 9 (Fig. 6j), for example, which is situated
$14 \mathrm{~m}$ from the shoreline and at a height of $2.85 \mathrm{~m}$ NGF. This block has a seaweed rim $25 \mathrm{~cm}$ wide and more than $50 \mathrm{~cm}$ in thickness extending over three quarters of its circumference. This bioconstructed rim exactly marks the base of the middle shore intertidal zone (Laborel et al., 1994).

Block 7 also shows traces of Lithophyllum thallus, but here they do not form a rim, either because the block was not submerged for a long enough or because the ledge was subsequently worn away during the movement of the block or its residence out of the water.

We can use Lithophyllum bissoïdes to evaluate the movement of these blocks from their initial environment to their present-day position several decimeters or meters above sea level and several meters from the shoreline (Fig. 5).

\subsection{Weight of blocks}

The mass of blocks was determined from the approximate volume obtained by the measurement of the width, height and length of blocks in the field and from the density of the limestones estimated by the combination of helium and dry powder pycnometry.

The Helium pycnometry has been performed on all samples using a stereopycnometer Quantachrome. This instrument allows us to obtain the skeletal density since the helium enters the finest connected pores of the rocks. The principle of the method is based on the estimation of the pressure change of helium in a calibrated volume.

Dry powder pycnometry, which allows to calculate the envelop density, has been performed on 3 samples. The principle of the method is based on the estimation of the 

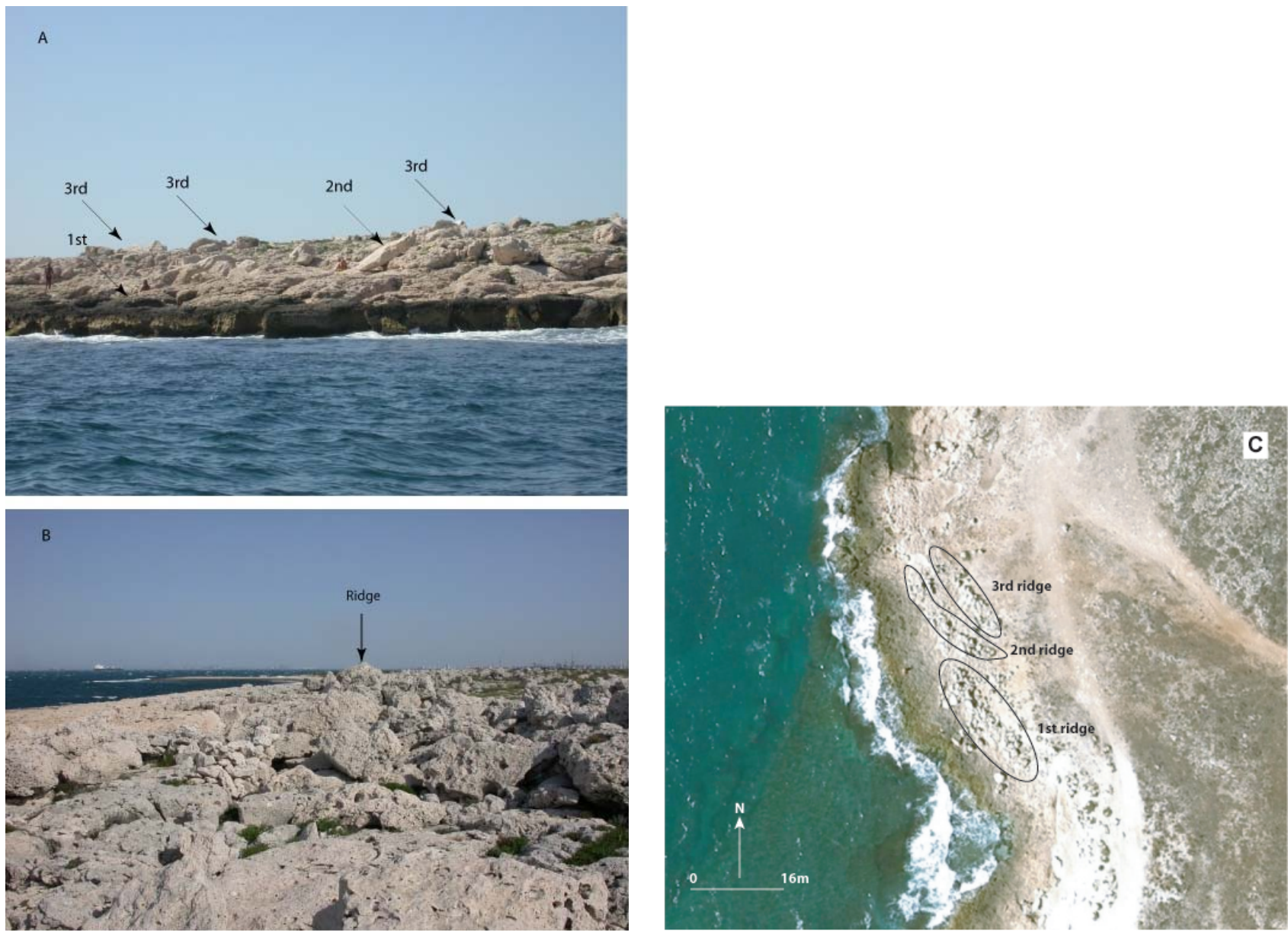

Fig. 6. Profiles on seaward side of blocks 3 and 10. (A) Clast deposits viewed from the sea and (B) clift-top clast deposits forming elongate train parallel to the coast in the upper part in the northern sector. (C) Clast accumulations in the southern sector of Arnette calanque forming three ridges parallel to the coast, which are successive in the case of ridges 2 and 3. (D), (E), (F) Tilted characteristic forms of littoral karst and notch after landward transport. (G), (H), (I), (J) Biological encrustation on boulders. (G) Lithophaga lithophaga. (H) Balanus sp. and microperforations of boring sponge (Cliona sp.). (I) Vermitidae. (J) Rim of Lithophyllum bissoïdes.

complementary volume of a container where the sample is placed using calibrated microspheres.

The difference between helium and dry powder methods allow to access the porosity of the samples. The resulting porosity estimates are $6.9 \%, 8.6 \%$ and $15.3 \%$. Considering the precision of the dry powder pycnometry and the heterogeneous distribution of the porosity within a plurimetric carbonate block, we considered an average porosity of $10 \%$ for mass calculation of all the blocks.

The density measurements so obtained display values around $2.4 \mathrm{~g} \mathrm{~cm}^{-3}$ (Table 1). The largest block is block 3 (Figs. 4 and 6e, f), which has an estimated weight of 33.5 tonnes. The topographic profile between the block and the sea is relatively flat, with a coastward slope at the end of the profile. This profile probably explains the great distance ( $39 \mathrm{~m}$ ) covered by block 3 (Fig. 5). On the contrary, block 9 (8.67 tonnes) has moved over a very steeply sloping profile to a height of $2.9 \mathrm{~m}$ NGF and over a distance of $14 \mathrm{~m}$ (Fig. 6). Other blocks have moved over shorter distances (Table 1).

\subsection{Radiocarbon dating}

The radiocarbon dating was carried out at the Pozna radiocarbon laboratory (Table 2). The dated samples correspond essentially to biological material fixed to rocks before their displacement due to wave action. The dated species include various rock-boring molluscs (Lithophaga sp. and Ballanus sp.), Lithophyllum and Vermitidae. The measurements were performed on the carbonate of shells and the individual thallus of seaweed. There is little possibility of contamination of the Lithophyllum or rock-borers by worm tubes, since we extracted the tube fragments from the limestone rock onto which the sample was attached. Otherwise, the tubes could be sampled by mistake and included in the sample for dating. Ten new samples are being dated, including different 

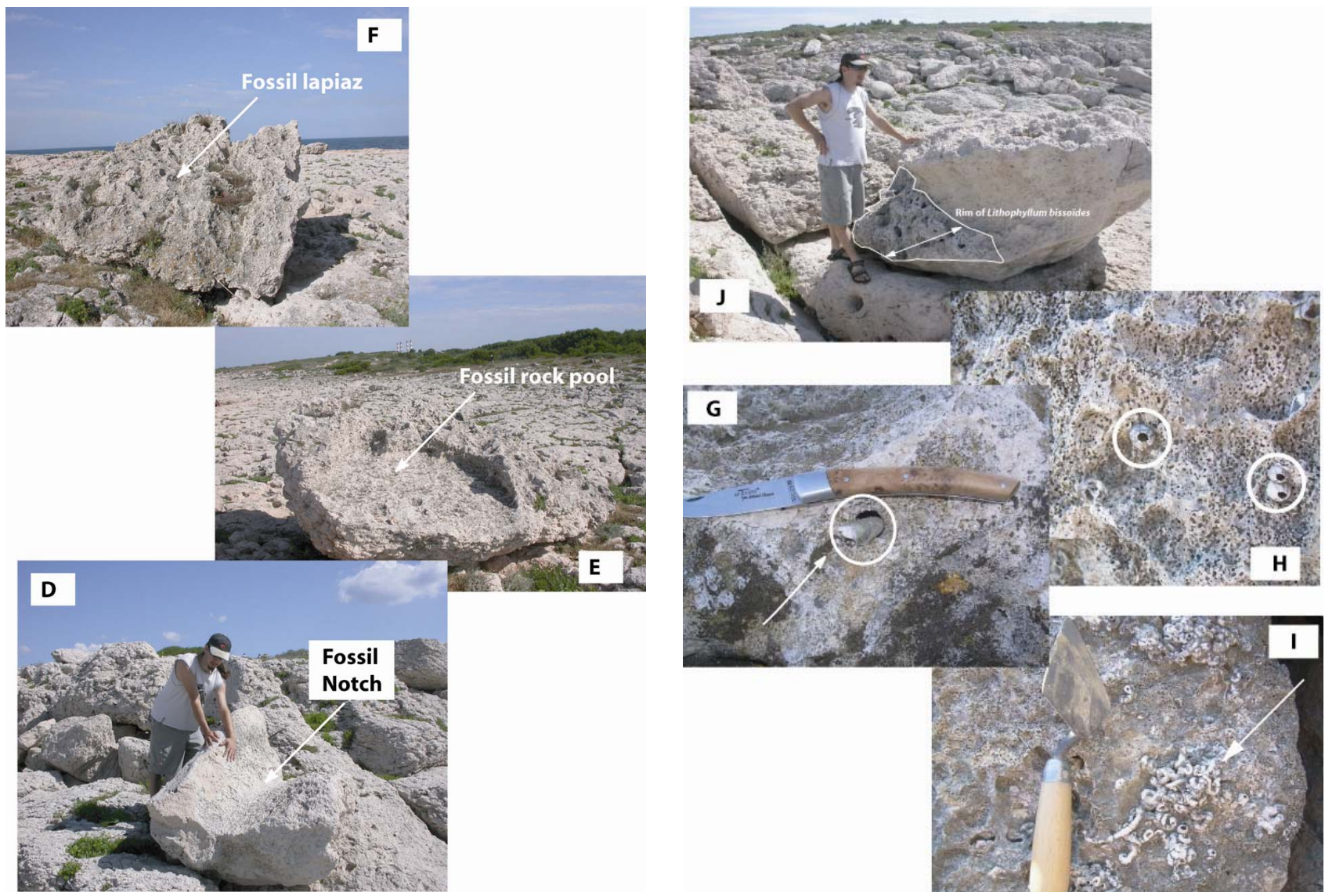

Fig. 6. Continued.

Table 1. Size, position and geological characteristics of boulders surveyed on the coast of the Gulf of Fos (a: long axis; b: width; c: thickness).

\begin{tabular}{|c|c|c|c|c|c|c|c|c|c|c|c|}
\hline Sample & Lithology & Latitude & Longitude & $\begin{array}{l}\text { Distance } \\
\text { from } \\
\text { the sea }\end{array}$ & $(\mathrm{m})$ & (m) & (m) & $\left(\mathrm{m}^{3}\right)$ & $\begin{array}{l}\text { Altititude } \\
\text { m.s.l. }\end{array}$ & $\begin{array}{c}\text { Average } \\
\text { density } \\
\text { considering } \\
10 \% \text { of } \\
\text { porosity } \\
\left(\mathrm{g} \mathrm{cm}^{-3}\right)\end{array}$ & $\begin{array}{c}\text { Estimated } \\
\text { weight }\end{array}$ \\
\hline Block3 & & $43^{\circ} 20.199^{\prime}$ & $5^{\circ} 01.747^{\prime}$ & 39.2 & 4.7 & 2.9 & 1.00 & 13.63 & 2.17 & 2.456 & 33.48 \\
\hline Block4 & $\triangleq$ & $43^{\circ} 20.214^{\prime}$ & $5^{\circ} 01.739^{\prime}$ & 29.5 & 1.8 & 1.3 & 0.5 & 1.17 & - & 2.468 & 2.89 \\
\hline Block5 & 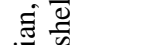 & $43^{\circ} 20.304^{\prime}$ & $5^{\circ} 01.568^{\prime}$ & 13.4 & 1.3 & 1.2 & 0.35 & 0.546 & 3.64 & 2.458 & 1.34 \\
\hline Block6 & ]$_{0}^{\infty} \cong$ & $43^{\circ} 20.298^{\prime}$ & $5^{\circ} 01.542^{\prime}$ & 4.70 & 1.80 & 1 & 0.60 & 1.728 & 1.48 & 2.448 & 4.23 \\
\hline Block7 & రై & $43^{\circ} 20.301^{\prime}$ & $5^{\circ} 01.537^{\prime}$ & 5 & 3.5 & 1.45 & 1.15 & 5.83 & 1.26 & 2.436 & 14.2 \\
\hline Block8 & 音 & $43^{\circ} 20.304^{\prime}$ & $5^{\circ} 01.543^{\prime}$ & 13.80 & 1.55 & 1.25 & 0.50 & 0.969 & 2.65 & 2.41 & 2.34 \\
\hline Block9 & స్తี & $43^{\circ} 20.304^{\prime}$ & $5^{\circ} 01.520^{\prime}$ & 14.20 & 2.3 & 1.95 & 0.8 & 3.588 & 2.87 & 2.416 & 8.67 \\
\hline Block10 & & $43^{\circ} 20.312^{\prime}$ & $5^{\circ} 01.491^{\prime}$ & 17.20 & 1.70 & 1.4 & 0.8 & 2.023 & 1.19 & 2.423 & 4.9 \\
\hline
\end{tabular}


Table 2. Samples of shells collected and dated by ${ }^{14} \mathrm{C}$ from biogenic encrustations on boulders, showing ages calibrated using calib5 (Stuiver and Reimer, 1993; Hugen et al., 2004).

\begin{tabular}{|c|c|c|c|c|c|c|c|c|c|}
\hline Sample & Latitude & Longitude & $\begin{array}{l}\text { Distance } \\
\text { from } \\
\text { the sea } \\
\text { (m) }\end{array}$ & $\begin{array}{l}\text { Volume } \\
\left(\mathrm{m}^{3}\right)\end{array}$ & $\begin{array}{l}\text { Height } \\
\text { a.m.s.l. } \\
\text { (m) }\end{array}$ & $\begin{array}{l}\text { Material } \\
\text { dated }\end{array}$ & $\begin{array}{l}\text { Laboratory } \\
\text { code }\end{array}$ & ${ }^{14} \mathrm{C}$ yr BP & $\begin{array}{l}\mathrm{Cal} \mathrm{BC} / \mathrm{AD} \\
2 \sigma \text { ranges }\end{array}$ \\
\hline Block2 & $43^{\circ} 20.302^{\prime}$ & $5^{\circ} 01.546^{\prime}$ & 12 & 0.3 & 2.18 & Serpulidae sp. & Poz-37456 & $415 \pm 30$ & $1772-<1950 \mathrm{AD}$ \\
\hline Block5 & $43^{\circ} 20.304^{\prime}$ & $5^{\circ} 01.568^{\prime}$ & 13.4 & 0.546 & 3.64 & Serpulidae sp. & Poz-37455 & $585 \pm 30$ & $1678-<1950 \mathrm{AD}$ \\
\hline Block6 & $43^{\circ} 20.298^{\prime}$ & $5^{\circ} 01.542^{\prime}$ & 4.70 & 1.728 & 1.48 & Balanus sp. & Poz-37454 & $108.19 \pm 0.34 \mathrm{pMC}$ & 1905-1930 AD \\
\hline Block7 & $43^{\circ} 20.301^{\prime}$ & $5^{\circ} 01.537^{\prime}$ & 5 & 5.83 & 1,26 & Lithophyllumbissoïdes & Poz-37461 & $895 \pm 30$ & $1678-<1950 \mathrm{AD}$ \\
\hline Block8 & $43^{\circ} 20.304^{\prime}$ & $5^{\circ} 01.543^{\prime}$ & 13.80 & 0.969 & 2.65 & Serpulidae sp. & Poz-37460 & $550 \pm 30$ & $1703-<1950 \mathrm{AD}$ \\
\hline Block9 & $43^{\circ} 20.304^{\prime}$ & $5^{\circ} 01.520^{\prime}$ & 14.20 & 3.588 & 2.87 & Lithophagalithophaga & Poz-37459 & $1035 \pm 30$ & $1292-1457$ AD \\
\hline Block10 & $43^{\circ} 20.312^{\prime}$ & $5^{\circ} 01.491^{\prime}$ & 17.20 & 2.023 & 1.19 & Serpulidae sp. & Poz-37457 & $4200 \pm 35$ & $2458-2100 \mathrm{BC}$ \\
\hline
\end{tabular}

pMC: percent modern carbon

biological materials from block 10, which appears to have been moved approximately $4000 \mathrm{BP}$ ago. This date seems very ancient considering that the sea level for this period would have been approximately $2 \mathrm{~m}$ lower than today (Vella et al., 2005).

Although the radiocarbon dates appear relatively close to each other, the statistical mean values are dispersed over a range of more than six centuries.

\section{Discussions and conclusions}

Although we cannot rule out the combined effects of tsunamis and storms to explain boulder accumulations along the rocky coast of the Gulf of Fos, these accumulations are most probably associated with exceptional south-westerly storms. The prevailing winds in this area are from the $\mathrm{N}$ and NW, especially in winter during the stormy season. The Gulf of Lion is notorious for bad weather and sudden changes of conditions. While strong NW winds, known as the Mistral, can be frequent, the wind rose shows another dominant direction from the S-SE creating a very-high-energy hydrodynamic regime with sea surges during onshore winds. The peculiar submarine morphology and orientation of the shoreline protect the study area from SE winds. On the contrary, being sheltered from south-easterly winds, the study area is very exposed to south-westerly to westerly winds and swells. The large fetch of the Gulf of Lion and the occurrence of rare but rather strong south-westerly winds could explain the displacement of megablocks by storms of exceptional force and unusual direction. On a local scale, the strength of the storm depends clearly on the local orientation of the coastline. Thus, in the case of this coast, the South-Westerly winds will create the strongest waves and swells (Ullmann et al., 2008). The rather uncommon occurrence of $160^{\circ} \mathrm{N}$ oriented coastlines in Provence could account for the scarcity of mega-boulder accumulations in this region.
The occurrence of numerous tsunamis in this region is not favoured because of the strong dispersal of radiocarbon ages, the presence of very fresh marks of movement and the very young ages (in the modern period) obtained from some blocks, which suggest a significant number of episodes of movement. In addition, historical data and information about tsunamis in France from 2000 BC to 1991 AD indicate only 35 events during this period (Soloviev et al., 1997). The moderate number of events and the weak amplitude of waves is more reduced in Marseille (4 events). In addition the most important events are observed in Nice-Cannes area to the east of the french coast (cf. Fig. 1a). The origin of these tsunamis is mostly related to ligurian earthquakes (Pelinovski et al., 2001, 2002). As for the SE storms, the studied site is protected from a tsunami wave of this direction. The relative sea level is well known in this area. Indeed a relative sea level curve has been established at Fos (Vella and Provansal, 2000) and confirmed by the sedimentary filling observed in the rias of the rocky coast studied here (Vella et al., 2011). The geographical conditions could explain the existence of exceptional storm events leading to the movement of blocks. However, we cannot totally exclude the impact of tsunami events that might have been involved in the formation of storm deposits.

Acknowledgements. The authors wish to thank the archaeological committee of Martigues city council and the director Jean Chausserie-Laprée, as well as Thomas Goslar from the Poznañ Radiocarbon Laboratory, and Carmelo Vella for technical assistance in the field. We would like to thank Raphaël Paris, Serge Suanez and anonymous reviewer for their helpful reviews. Michael Carpenter post-edited the English style.

Edited by: E. Pelinovsky

Reviewed by: R. Paris and another anonymous referee 


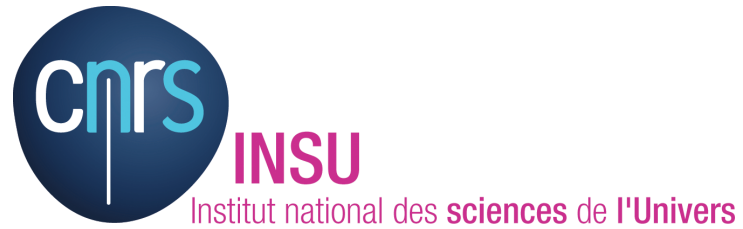

The publication of this article is financed by CNRS-INSU.

\section{References}

Barabano, M. S., Pirrotta, C., and Gerardi, F.: Large boulders along the south-eastern Ionian coast of Sicily: Storm or tsunami deposits?, Mar. Geol., 275(1-4), 140-154, doi:10.1016/j.margeo.2010.05.005, 2010.

Chorowitz, J. and Paul, S.: Mise en évidence des linéaments, en Provence Occidentale, sur des images obtenues par le satellite ERTS-1, leur signification structurale, Bull. Soc. Geol. de Fr., 7, 491-497, 1974 (in French).

Court-Picon, M., Vella, C., Chabal, L., and Brunetion, H.: Paléoenvironnements littoraux depuis $9000 \mathrm{BP}$ sur la bordure occidentale du Golfe du Lion: le lido du bassin de Thau, Quaternaire, 21/1, 27-41, 2010 (in French).

Etienne, S. and Paris, R.: Boulder accumulations related to storms on the south coast of the Reykjanes Peninsula (Iceland), Geomorphology, 114(1-2), 55-70, doi:10.1016/j.geomorph.2009.02.008, 2010.

Goff, J., Dudley, W. C., De Maintenon, M. J., Cain, G., and Coney, J. P.: The largest local tsunami in 20th century Hawaii, Mar. Geol., 226(1-2), 65-79, doi:10.1016/j.margeo.2005.09.017, 2006.

Goto, K., Okada, K., and Imamura, F.: Characterictics and hydrodynamics of boulders transported by storm wave at Kudaka Island, Japan, Mar. Geol., 262(1-4), 14-24, doi:10.1016/j.margeo.2009.03.001, 2009.

Goto, K., Miyagi, K., Kawana, T., Takahashi, J., and Imamura, F.: Emplacement and movment of boulders by known storm wavesfield evidence from the Okinawa Islands, Japan, Mar. Geol., doi:10.1016/j.margeo.2010.09.007, in press, 2011.

Hughen, K. A., Baillie, M. G. L., Bard, E., Beck, J. W., Bertrand, C. J. H., Blackwell, P. G., Buck, C. E., Burr, G. S., Cutler, K. B., Damon, P. E., Edwards, R. L., Fairbanks, R. G., Friedrich, M., Guilderson, T. P., Kromer, B., McCormac, G., Manning, S., Bronk Ramsey, C., Reimer, P. J., Reimer, R. W., Remmele, S., Southon, J. R., Stuiver, M., Talamo, S., Taylor, F. W., van der Plicht, J., and Weyhenmeyer, C. E.: Marine04 marine radiocarbon age calibration, 0-26 cal kyr BP, Radiocarbon, 46(3), 10591086, 2004.

Kelletat, D. and Schellmann, G.: Tsunami on Cyprus: field evidences and 14C dating results, Z. Geomorphologie, 46(1), 1934, 2002.

Laborel, J., Morhange, C., Lafont, R., Le Campion, J., LaborelDeguen, F., and Sartoretto, S.: Biological evidence of sea-level rise during the last 4500 years on the rocky coast of continental southwestern France and Corsica, Mar. Geol., 120(3-4), 203223, doi:10.1016/0025-3227(94)90059-0, 1994.

Maouche, S., Morhange, C., and Meghraoui, M.: Large boulder accumulation on the Algerian coast evidence tsunami events in the western Mediterranean, Mar. Geol., 262, 96-104, 2009.
Mastronuzzi, G. and Sansò, P.: Boulders transport by catastrophic waves along the Ionian coast of Apulia (Southern Italy), Mar. Geol., 170(1-2), 93-103, doi:10.1016/S0025-3227(00)00068-2, 2000.

Mastronuzzi, G. and Sansò, P.: Large boulder accumulations by extreme waves along the Adriatic coast of southern Apulia (Italy), Quatern. Int., 120, 173-184, doi:10.1016/j.quaint.2004.01.016, 2004.

Mastronuzzi, G., Pignatelli, C., Sansò, P., and Selleri, G.: Boulder accumulations produced by the 20th February, 1743 tsunami along the coast of southeastern Salento (Apulia region, Italy), Mar. Geol., 242(1-3), 191-205, doi:10.1016/j.margeo.2006.10.025, 2007.

Morhange, C., Laborel, J., and Hesnard, A.: Changes of relative sea level during the past 5000 years in the ancient harbor of Marseilles, Southern France, Palaeogeogr., Palaeocl., Palaeoeco., 166, 319-329, 2001.

Morhange, C., Mariner, N., and Pirazzoli, P.A.: Evidence of lateholocene tsunami events from Lebanon, Z. Geomorphol., 146, 81-95, 2006.

Nott, J.: Records of prehistotic tsunamis from boulder deposits: evidence from Australia, Science of Tsunami Hazards, 18, 3-14, 2000.

Paris, R., Wassmer, P., Sartohaldi, J., Barthomeuf, B., Desgages, E., Grancher, D., Baumert, P., Vautier, F., Brunstein, D., and Gomez, C.: Tsunmais as geomorphic crisis:lessons from December 26, 2004 tsunami in Lhok Nga, west banda Aceh (Sumatra, Indonesia), Geomophology, 104(1-2), 59-72, doi:10.1016/j.geomorph.2008.05.040, 2009.

Nott, J.: The tsunami hypothesis-comparisons of the field evidence against the effects, on the Western Australian coast, of some of the most powerful storms on earth, Mar. Geol., 208(1), 1-12, doi:10.1016/j.margeo.2004.04.023, 2004.

Noormets, R., Crook, K. A. W., and Felton, E. A.: Sedimentology of rocky shorelines: 2. shoreline megaclasts on the north shore of Oahu Hawaii - origins and history, Sediment. Geol., 150, 31-45, doi:10.1016/S0037-0738(01)00266-4, 2002.

Pelinovsky, E., Kharif, C., Riabov, I., and Francius, M.: Study of tsunami propagation in the Ligurian Sea, Nat. Hazards Earth Syst. Sci., 1, 195-201, doi:10.5194/nhess-1-195-2001, 2001.

Pelinovsky, E., Kharif, C., Riabov, I., and Francius, M.: Modelling of tsunami propagation in the vicinity of the French coast of the mediterranean, Nat. Hazards, 25(2), 135-159, doi:10.1023/A:1013721313222, 2002.

Recorbet, F., Rochette, P., Braucher, R., Bourlès, D., Benedetti, L., Hantz, D., and Finkel, R. C.: Evidence for active retreat of a coastal cliff between 3,5 and $12 \mathrm{ka}$ in Cassis (South East France, Geomorphology, 115, 1-10, doi:10.1016/j.geomorph.2009.04.023, 2010.

Sabatier, F., Samat, O., Ullmann, A., and Suanez, S.: Connecting large-sacle coastal behaviour with coastal managment of the Rhône delta, Geomorphology, 107, 79-89, doi:10.1016/j.geomorph.2006.09.026, 2009.

Scheffer, A. and Scheffers, S.: Tsunami deposits on the coastline of west Crete (Greece), Earth Planet. Sc. Lett. 259, 613-624, doi:10.1016/j.eps1.2007.05.041, 2007.

Soloviev, S. L., Solovieva, O. N., Go, Ch. N., Kim, Kh. S., and Shetnikov, N. A.: Tsunamis in the Mediterranean sea 2000 B.C.2000 A.D., vol. 13, in: Advances in Natural and technological 
hazards Research, Kluwer, Dordrecht, 1997.

Stuiver, M. and Reimer, P. J.: Extended ${ }^{14} \mathrm{C}$ Data-Base and Revised Calib $3.0{ }^{14} \mathrm{C}$ Age Calibration Program, Radiocarbon, 35(1), 215-230, 1993.

Suanez, S., Fichaut, B., and Magne, R.: Cliff-top storm deposits on Banneg island, Brittany, France: Effect of giant waves in the Eastern Atlantic Ocean, Sediment. Geol., 220, 12-28, 2009.

Ullmann, A., Pirazzoli, P. A., and Moron, V.: Sea surges around the Gulf of Lions and atmospheric conditions, Global Planet. change, 63, 203-214, doi:10.1016/j.gloplacha.2007.10.002, 2008.

Vella, C. and Provansal, M.: Relative sea-level rise and neotectonic events during the last 6000 years on the southern eastern Rhône delta, France, Mar. Geol., 170, 27-39, doi:10.1016/S00253227(00)00063-3, 2000.
Vella, C., Fleury, T. J., Racassi, G., Provansal, M., Sabatier, F., and Bourcier, M.: Evolution of the Rhône delta plain in the Holocene, Mar. Geol., 222-223, 235-265, doi:10.1016/j.margeo.2005.06.028, 2005.

Vella, C., Pailles, C., Canut, V., Beaudoin, C., Duval, S., Chausserie-Laprée J., and Bourcier, M.: Marine transgression in a Mediterrannean ria during the Holocene, submitted, 2011.

Vött, A., May, M., Brückner, H., and Brockmüller, S.: Sedimentary evidence of late Holocene Tsunami events near Lefkada Island (NW Greece), Z. Geomorphol., 146, 139-172, 2006.

Williams, D. M. and Hall, A. M.: Cliff-top megaclasts deposits of ireland, a record of extrem waves in the North Atlantic-sortms or tsunamis?, Mar. Geol., 206, 101-117, doi:10.1016/j.margeo.2004.02.002, 2004. 